\title{
Importance of different trophic pathways in a nearshore benthic community under upwelling and downwelling conditions
}

\author{
F. V. Wulff ${ }^{1}$ and J. G. Field ${ }^{2}$ \\ ${ }^{1}$ Institute of Marine Ecology, The Askö Laboratory, University of Stockholm, S-10691 Stockholm, Sweden \\ ${ }^{2}$ Department of Zoology, University of Cape Town, Rondebosch 7700, South Africa
}

\begin{abstract}
A simulation model is used as a tool to investigate possible ecological effects of upwelling and downwelling water transport on trophic relationships in a kelp bed off the Cape Peninsula, South Africa. The model is based on many years of field and experimental data of energy fluxes between trophic compartments in a community dominated by filter feeders which consume phytoplankton, detritus derived from seaweeds, and animal faeces. The model is simple, yet incorporates feedback loops via faeces and control by predators and is used to calculate the relative amounts of food that filter feeders require from the different sources available to balance their energy needs and maintain a steady biomass. When modelled as a closed system, steady state is maintained by major flows through a feedback loop via faeces and bacteria in a detrital food chain. This is analogous to semi-closed systems such as certain estuaries and salt marshes. Under continuous downwelling conditions, phytoplankon from the rich Benguela pelagic zone enters the kelp bed and may form up to $93 \%$ of filter feeder food with rapid water exchange. This is similar to many phytoplankton-based nearshore systems. Under continuous upwelling conditions, consumer biomass is limited by food availability since detritus is exported and no phytoplankton is imported. This has been confirmed by observations for which there are few, if any, other published accounts. Under a realistic pulsing regime simulating conditions in the southern Benguela region, consumer biomass reaches steady state oscillation within 7 yr, increasing in biomass during winter and decreasing during the summer upwelling season. Sensitivity analyses show that pulse duration has less effect than the rate of water transport. The study demonstrates the role of a feedback loop in maintaining large animal biomasses in a detrital food chain and the importance of advective water transport in an open coastal ecosystem. It also shows the damping control on the system by predators, in this instance mainly the exploited rock lobster Jasus lalandii.
\end{abstract}

\section{INTRODUCTION}

Marine upwelling areas are well known for supporting high primary production and pelagic fisheries but less well for their rich benthic communities. Of these, kelp beds are found off the African west coast from Cape Agulhas in the south to the Ugab River (Namibia) in the north, covering the rocky intertidal bottoms as deep as $35 \mathrm{~m}$ (Field et al., 1980a). These belts have been intensively studied off the west coast of the Cape Peninsula, South Africa, where they are dominated by the large kelps Ecklonia maxima and Laminaria pallida (Field et al., 1977; Velimirov et al., 1977).

Primary production by the kelps, understorey algae and epiphytes amounts to some $767 \mathrm{~g} \mathrm{C} \mathrm{m}^{-2} \mathrm{yr}^{-1}$ (Mann et al., 1979; Dieckmann, 1980; Jarman and Carter, 1981), while that of phytoplankton in the kelp beds, based on studies by Borchers and Field (1981) and Carter (1982), is estimated to be $506 \mathrm{~g} \mathrm{C} \mathrm{m}^{-2} \mathrm{yr}^{-1}$ (Newell et al., 1982). Thus $63 \%$ of the primary production in kelp beds is by macrophytes, and since fewer than $5 \%$ of the consumers in the community are grazers, the production is likely to pass along detritus food chains to the filter feeders which dominate the community (Velimirov et al., 1977). Studies on the carbon absorption efficiency of the major filter feeder in the community, Aulacomya ater, show that it is able to ingest and absorb debris and faeces directly with efficiencies of 40 to $60 \%$ (Stuart et al., 1982a, b). Detritus kept in suspension by wave action may be refiltered again and again, and if a major fraction is assimilated directly, the calculated needs of the consumers might be met by the total primary production within the kelp bed. 
However, is it really realistic to look upon these kelp beds as 'closed' systems where primary production must balance consumption and energy dissipation? In reality, the kelp beds are found along a highly exposed coastline, and Field et al. (1981) have shown that the whole water column within a kelp bed may be replaced 3 to 7 times $d^{-1}$. If upwelling is accompanied by heavy wave action that keeps the particles in suspension, large amounts of POM may be carried out of the system with the upwelling water.

While it has been possible to measure rates of water transport into and out of kelp beds directly (Field et al., 1981), and to estimate the frequency of upwelling and downwelling events at different seasons, in practice it is impossible to measure directly the effect of such events on the functioning of the food web. However, by combining the available information on primary production and the nature of suspended material under different environmental conditions with some detailed data on the physiology of the main filter feeder in the kelp-bed community, the mussel Aulacomya ater (Griffiths and King, 1979a, b, ; Stuart et al., 1981, 1982a, b; Stuart, 1982), it is possible to construct a mathematical simulation model to do this.

The aim of this study is to see whether there are variations in the food web structure of the biological community in relation to physical factors, interactions which are not easily measured directly. For this purpose, we have set up a simple mathematical model of a kelp bed on the west coast of the Cape Peninsula, South Africa. The model aims to explore the effect of various regimes of water exchange on the balance between primary production and consumption (the degree of self-maintenance), and on whether filter feeders are supported by detritus-or phytoplanktonbased food chains.

\section{THE MODEI}

\section{Basis and structure}

The simulation model is based on measurements of biomass and energy flows for the major trophic groups.
The total annual primary production of macrophytes is estimated at $38,204 \mathrm{~kJ} \mathrm{~m}^{-2} \mathrm{yr}^{-1}$ (Newell et al., 1982). About $30 \%$ of this $\left(10,066 \mathrm{~kJ} \mathrm{~m}^{-2} \mathrm{yI}^{-1}\right)$ is released as dissolved organic matter (DOM), most of the remainder being eroded from the tips of the fronds as particulate debris (POM) (Newell et al., 1980). Based on measurements by Brown (1981) and Borchers and Field (1981), the annual phytoplankton primary production within the kelp community has been estimated to be $23,986 \mathrm{~kJ}$ $\mathrm{m}^{-2} \mathrm{yr}^{-1}$ (Newell et al., 1982). Thus the total annual primary production is $62,190 \mathrm{~kJ} \mathrm{~m}^{-2} \mathrm{yr}^{-1}$, which is very close to the $54,037 \mathrm{~kJ} \mathrm{~m}^{-2} \mathrm{yr}^{-1}\left(1,130 \mathrm{~g} \mathrm{C} \mathrm{m}^{-2} \mathrm{yr}^{-1}\right)$ estimated for the phytoplankton community in adjacent deeper waters (Brown, 1981).

Energy budget calculations for consumers have been synthesized by Newell et al. (1982) and are summarised in Table 1. Filter-feeders are the dominant consumers, constituting $72 \%$ of the total biomass and $94 \%$ of the animal respiration. Basic components are mussels $(45.7 \%)$, sponges $(12.5 \%)$ and ascidians $(5.7 \%)$. The grazers (sea urchins and gastropods) constitute less than $5 \%$ of the biomass; their energy flows are omitted from the model. Camivores are separated into large forms like the rock lobster Jasus lalandii, anemones and fishes, and small forms like the isopods Cirolana imposita, but have been pooled into one category in this model.

Fig. 1 shows the highly simplified model of the kelp bed used in this analysis, drawn in the energy circuit language of Odum (1972). The animals have been separated into filter feeders and carnivores, the components that contribute most to the biomass and energy flows. The picture model illustrates that the kelp POM and phytoplankton production can either be consumed directly by the filter feeders or as bacterial biomass after microbial degradation. The same pathways also apply to the faeces where the unassimilated food fractions are returned as suspended organic particles to the water column. DOM must first be converted to bacteria before it is available as food. Downward energy flows ending in electrical grounding symbols represent the energy losses due to respiration that takes place with each energy transformation in the system. The small and large carnivores (listed in Table 1) have been

Table 1. Standing stocks $\left(\mathrm{kJ} \mathrm{m}^{-2}\right)$ and energy flows $\left(\mathrm{kJ} \mathrm{m}^{-2} \mathrm{yr}^{-1}\right.$ for the consumers in the South African kelp beds. (After Newell et al., 1982)

\begin{tabular}{|c|c|c|c|c|c|}
\hline & $\begin{array}{c}\text { Biomass } \\
\mathrm{B}\end{array}$ & $\begin{array}{c}\text { Production } \\
\text { P }\end{array}$ & $\begin{array}{c}\text { Respiration } \\
\text { R }\end{array}$ & $\begin{array}{c}\text { Consumption } \\
\mathrm{C}\end{array}$ & $\begin{array}{c}\text { Faeces } \\
\text { F }\end{array}$ \\
\hline Grazers & 300 & 312 & 1,083 & 4,650 & 1,588 \\
\hline Filter feeders & 5,155 & 5,825 & 30,930 & 62,891 & 26,033 \\
\hline Large carnivores & 1,579 & 632 & 411 & 3.160 & 1,264 \\
\hline Small carnivores & 149 & 826 & 648 & 4,131 & 289 \\
\hline
\end{tabular}




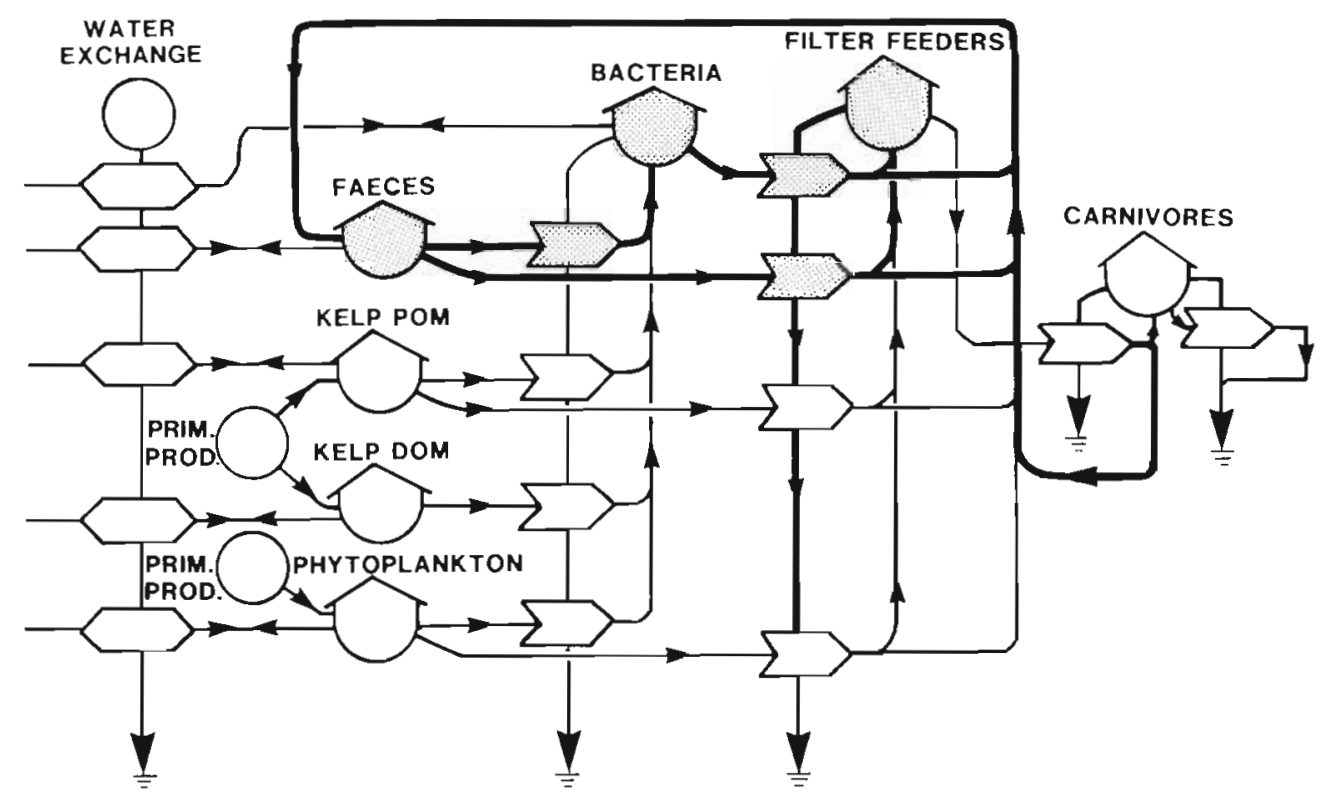

Fig. 1. Simplified model of an idealised Benguela kelp bed, expressed in the energy circuit language of Odum (1972). Energy sources are indicated as circles; roofed circles ('bird-houses') represent storages of energy; one- or two-way open arrows indicate one- or two-way work gates allowing the appropriate passage of energy. Electrical earth symbols represent heat sinks, or energy given off in energy transformations (respiration). Interactions between the components of the model are described in the text. The 'faeces loop' is emphasized by shading and heavier lines

lumped into one compartment since they occupy the same general trophic position. Grazers are excluded since they constitute less than $5 \%$ of the total animal biomass and energy flows. The energy budgets, with production $(\mathrm{P})$, consumption $(\mathrm{C})$, respiration $(\mathrm{R})$, and faeces $(F)$, related to biomass $(B)$ are modified from the data in Newell et al. (1982) and shown in Table 2. The major difference is that we have deliberately omitted the poorly understood rates of excretion (U) in the energy budgets and assumed that consumption is balanced by production, respiration and faeces. Thus, in this model, absorption (C-F) and assimilation $(\mathrm{P}+\mathrm{R})$ are equal and used interchangeably.

In the model the biomass of the filter feeders is controlled by the amount of food available, by respiration, and by the predation of carnivores. The carnivores are controlled by the amount of food (i. e. filter-feeders), respiration, and by density-dependent mortality. This mortality rate is equal to the net production at biomasses of 5,155 and $1,728 \mathrm{~kJ} \mathrm{~m}^{-2}$ for filter feeders and carnivores respectively. Thus the biomasses will reach a steady state at the mean biomasses found for the kelp bed when food is not limiting. The differential equations for filter feeder (FF) and for carnivore (CA) biomasses are then:

$$
\begin{aligned}
& \mathrm{dFF} / \mathrm{dt}=\mathrm{FF} \cdot \mathrm{FASS}-\mathrm{FR} \cdot \mathrm{FF}-\mathrm{CCONS} \cdot \mathrm{FF} \cdot \mathrm{CA} \\
& \mathrm{dCA} / \mathrm{dt}=\mathrm{CASS} \cdot \mathrm{FF} \cdot \mathrm{CA}-\mathrm{CR} \cdot \mathrm{CA}-\mathrm{CMORT} \cdot \mathrm{CA} \\
& \cdot \mathrm{CA}
\end{aligned}
$$

The constants, scaled in units of $\mathrm{kJ} \mathrm{m}^{-2} \mathrm{~d}^{-1}$, are derived from the values given in Tables 1 and 2 . FASS is the amount of suspended food assimilated per unit filterfeeder biomass. FR $\left(1.64 \cdot 10^{-2}\right)$ is the respiration per biomass for the filter feeders and CCONS $\left(1.79 \cdot 10^{-2}\right)$ is filter-feeder mortality due to consumption by carnivores. CASS $\left(0.4322^{\circ}\right.$ CCONS) is the assimilated fraction of the food consumed by carnivores, CR $(0.168$ * $10^{-2}$ ) is their respiration per unit biomass, and CMORT $\left(1.338 \cdot 10^{-6}\right)$ is instantaneous mortality rate.

Table 2. Initial values of maximum annual production (P), respiration (R), consumption (R), faeces (F) and assimilation (A) related

\begin{tabular}{|c|c|c|c|c|c|c|}
\hline & $\mathrm{P} / \mathrm{B}$ & $R / B$ & $\mathrm{C} / \mathrm{B}$ & $\mathrm{F} / \mathrm{B}$ & $\mathrm{P} / \mathrm{C}$ & $\mathrm{A} / \mathrm{C}$ \\
\hline Filter feeders & 1.13 & 6.00 & 12.18 & 5.05 & 0.088 & 0.585 \\
\hline Carnivores & 0.843 & 0.613 & 3.371 & 1.914 & 0.250 & 0.432 \\
\hline
\end{tabular}
to biomass $(B)$ and consumption. These ratios remain constant for carnivores but $C$ and $P$ for the filter feeders vary due to differences in food, electivity and assimilation efficiencies in different simulations 


\section{Consumption by filter feeders}

All the food resources of filter feeders originate ultimately from the primary production of kelp and phytoplankton. These are kept as constant inputs in the model in order to explore the effects of other changes. However, there are several pathways by which food can reach filter feeders and the efficiency of energy (or carbon) conversion in most of these steps is known from experimental work on microcosms using nonenriched local sea water (Linley and Newell, 1981; Linley et al., 1981; Lucas et al., 1981; Newell and Lucas, 1981; Newell, 1983; Stuart et al., 1981, 1982a). These results have been synthesized by Newell et al. (1982). We have also used the primary production estimates of Newell et al. (1982), but have substracted the small fraction of kelp production utilized by grazers from the production of kelp, since it is not relevant to this model.

In order to study the relationship of the filter feeder and detrital/microbial food chains to the production/ consumption balance of the system, we changed food electivities and assimilation efficiencies. An electivity index (E) was assigned for each food item, giving the percentage of the food particles that may be consumed by the filter feeders. For instance, it is unlikely that all faeces or kelp POM are suspended in the water column or in particles within the size range that can be filtered. Field studies have shown that the particle size range of suspended POM in the kelp bed varies according to swell height (Field et al., 1981) and experimental work on bivalves and sponges has shown varying abilities to clear particles of different sizes among the different species (Reiswig, 1974, Møhlenberg and Riisgård, 1978). We have therefore tested the model with electivity indices ranging between 0.1 and 0.9 .

The assimilation efficiencies (A) for the different food items were also varied between 0.1 and 0.9 . However, in order to limit the number of possible combinations we have, in most simulations, assumed that the same electivity and assimilation efficiency applies for the combination of phytoplankton and bacteria $\left(A_{p}=A_{b}=E_{p}=E_{b}\right)$ as well as for the combination of kelp POM and faeces $\left(A_{k}=A_{f}=E_{k}=E_{f}\right)$. We have also assumed that $A$ and $E$ for kelp POM and faeces can never be higher than for phytoplankton and bacteria.

The total amount of food available to be assimilated by the filter feeders is calculated by summation of the available fractions of the food items, determined by their electivity and assimilation efficiencies:

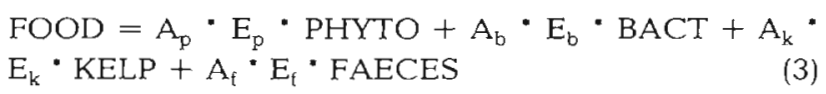

When the amount of assimilable food (FOOD) is greater than needed for the maximum $A / B$ ratio of the filter feeders (ABMAX $=P / B+R / B=7.13 Y^{-1}$, see Table 2), the assimilation rate per biomass (FASS) is equal to the maximum ratio (ABMAX). At lower concentrations all assimilable food is consumed:

IF $F O O D>=A B M A X \cdot F F$ THEN FASS $\cdot F F=$ $A B M A X \cdot F F \cdot E L S E$ FASS $\cdot F F=$ FOOD

Each of the different food items is consumed in relation to its proportion in the total assimilable food. The consumption per unit biomass is given by:

$\mathrm{FCONS}=\left(E_{\mathrm{p}} \cdot\right.$ PHYTO $/ \mathrm{A}_{\mathrm{p}}+\mathrm{E}_{\mathrm{b}} \cdot \mathrm{BACT} / \mathrm{A}_{\mathrm{b}}+\mathrm{E}_{\mathrm{k}} \cdot$ $\left.\mathrm{KELP} / \mathrm{A}_{\mathrm{k}}+\mathrm{E}_{\mathrm{f}} \cdot \mathrm{FAECES} / \mathrm{A}_{\mathrm{f}}\right) / \mathrm{FOOD}$

\section{Bacterial activity}

We have assumed that the fractions of the food not available to the filter feeders (l-E) are subjected to microbial degradation. Most of the studies on carbon conversion efficiencies show values around $10 \%$ (Newell and Lucas, 1981). The low ratios were all obtained during downwelling conditions with low nitrogen concentrations, and preliminary experimental results suggest that it is likely that these conversion efficiencies may increase up to $40 \%$ under upwelling conditions when the bacteria can utilise nitrogen rich substrates (R. C. Newell, pers. comm.). We have therefore used a bacterial conversion efficiency $\left(\mathrm{CC}_{\mathrm{b}}\right)$ of 0.1 for all substrates to represent downwelling situations, and tested the model with both 0.1 and 0.4 under upwelling conditions in order to explore the effects of variations in the carbon conversion efficiency.

The studies on bacterial production efficiencies also supply estimates on rates of substrate degradation. About $50 \%$ of DOM released by the kelp is utilised in $5 \mathrm{~d}$ (Lucas et al., 1981) and $50 \%$ of POM and faeces are broken down in $15 \mathrm{~d}$ (Stuart et. al., 1981, 1982a). We have assumed that $15 \mathrm{~d}$ is also representative of phytoplankton debris degradation (Newell et al., 1981). The net production of bacterial biomass from the different sources of organic matter is then:

BPROD $($ PHYTO $)=\left(1-E_{p}\right) \cdot \mathrm{PHYTO} * \mathrm{DS}_{\mathrm{p}} \cdot \mathrm{CCb}$ $\mathrm{BPROD}(\mathrm{KELP} P O M)=\left(1-\mathrm{E}_{\mathrm{k}}\right) \cdot \mathrm{KELP} \cdot \mathrm{DS}_{\mathrm{k}}{ }^{*} \mathrm{CC}_{\mathrm{b}}$ $\mathrm{BPROD}(\mathrm{DOM})=\mathrm{DOM} \cdot \mathrm{DS}_{\mathrm{d}} \cdot \mathrm{CC}_{\mathrm{b}}$ BPROD $(B A C T)=\left(1-E_{b}\right) \cdot B A C T \cdot \mathrm{DS}_{b} \cdot \mathrm{CC}_{b}$ $\operatorname{BPROD}($ FAECES $)=\left(1-\mathrm{E}_{\mathrm{f}}\right) \cdot \mathrm{FAECES} \cdot \mathrm{DS}_{\mathrm{f}}{ }^{*} \mathrm{CC}_{b}$

where DS is the percent of substrate broken down per day, which is 0.033 for phytoplankton, kelp POM and faeces $\left(\mathrm{DS}_{p}, \mathrm{DS}_{k}, \mathrm{DS}_{\mathrm{f}}\right)$ and 0.1 for DOM $\left(\mathrm{DS}_{\mathrm{d}}\right)$. The total bacterial consumption is then:

$\mathrm{BCONS}=\mathrm{BPROD} / \mathrm{CC}_{\mathrm{b}}$ 


\section{Water exchange}

The suspended and dissolved organic matter can be transported into or out of the system by water movements. If the concentration of a substance is higher outside than inside the kelp bed, outward water exchange will cause a net loss, and vice versa. The formulation used to describe the net transport of any substance (in $\mathrm{kJ} \mathrm{m}^{-2} \mathrm{~d}^{-1}$ ) is:

\section{NETTRANSPORT $=$ EXCHANGE $\cdot($ EXTCONC - INTCONC)

Where EXCHANGE is the number of times the whole water column $\left(10 \mathrm{~m}^{-3}\right)$ is replaced each day, and EXTCONC and INTCONC are the concentrations (KJ $\mathrm{m}^{-3}$ ) of the particular substance outside and inside the kelp bed. We have assumed that the concentrations of kelp POM, DOM, faeces and bacteria are zero in the water entering the kelp bed. The phytoplankton concentration and production inside the system are set to zero during upwelling conditions, when clear, deep water enters the system. During downwelling, when surface offshore water is brought into the system, phytoplankton concentration is assumed to be $65.28 \mathrm{~kJ}$ $10 \mathrm{~m}^{-3}$, corresponding to the mean daily production within the system (Brown, 1981).

The generalised differential equation describing the change in the suspended and dissolved food substances is:

$\mathrm{d}($ SUBSTANCE) $/ \mathrm{dt}=$ NETTRANSPORT (SUBS.) + PROD (SUBS) - BCONS (SUBS.) - FCONS (SUBS)

The net transport, bacterial and filter-feeder consumption have been described above. Net production values of different substances converted to daily rates (in $\mathrm{kJ} \mathrm{m}^{-2} \mathrm{~d}^{-1}$ ) are given by:

PROD $(\mathrm{PHYTO})=65.28$ or 0 (down- or upwelling)

PROD (KELP POM) $=62.25$

$\operatorname{PROD}(\mathrm{DOM})=27.27$

PROD $(\mathrm{BACT})=\mathrm{BPROD}(\mathrm{PHYTO})+\mathrm{BPROD}(\mathrm{KELP})+$ BPROD (DOM) + BPROD (FAECES)

$\mathrm{PROD}(\mathrm{FAECES})=\mathrm{FF} *(\mathrm{FCONS}-\mathrm{FASS})+\mathrm{CA} \cdot$ (CONS - CASS)

\section{Patterns of down- and upwelling}

Seasonal wind patterns show prevailing south easterly winds during the southern summer (Sept-Apr) causing upwelling. During winter (May-Aug) north westerly winds prevail causing downwelling (Andrews and Hutchings, 1980). Many observers (see Field et al., 1980b) have noticed that the turbid water in the kelp beds is replaced by clear, upwelled water within a few hours of the commencement of a strong SE wind. The newly upwelled water is characterised by high nutrient concentrations (Andrews and Hutchings, 1980) but the particulate concentration and phytoplankton production are negligible (Brown, 1981; Barlow, 1982). Under these conditions, phytoplankton production reaches its maximum further offshore in a more stratified water column (Brown, 1980). As upwelling water moves offshore it carries with it a proportion of the faeces, kelp POM and DOM produced within the kelp beds. Large quantities of the material will also be exported during downwelling but phytoplankton produced offshore is then transported into and through the system, thus providing an additional food resource. A closed system is approached only during calm conditions or when currents change rapidly when the same water may be transported in and out the kelp beds.

Although the southern Benguela region has a welldefined upwelling season, comparison with other regions indicates that this area is subjected to short-term variations due to the rapidly changing and often very fierce winds (Andrews and Hutchings, 1980). Typically, a strong SE wind blows for only a few days, followed by moderate SE winds changing to NW. The kelp community is therefore exposed to short-term and to seasonal variability that may have a profound influence on exports, imports and production of food in the system.

Based on data of speed, direction and duration of winds obtained during 1979-1981 at Olifantsbos, on the west coast of the Cape Peninsula near our study sites, it was possible to estimate the frequency and duration of upwelling and downwelling during a year. During the 8 summer months, strong $\left(>12 \mathrm{~m} \mathrm{~s}^{-1}\right) \mathrm{SE}$ winds with an average duration of $3.4 \mathrm{~d}$ are followed by moderate (5-12 $\mathrm{m} \mathrm{s}^{-1}$ ) SE winds for $2.2 \mathrm{~d}$. These winds cause strong to moderate upwelling and are usually followed by a few days (mean duration of $4.2 \mathrm{~d}$ ) of calm conditions or moderate NW winds, often causing downwelling. This sequence tends to be repeated throughout the summer. 'Strong', upwelling occurs for $42 \%$, 'medium' upwelling for $25 \%$, and 'downwelling' for the remaining $33 \%$ of the summer period (G. Nelson, Sea Fisheries Inst., pers. comm.), During winter, calm conditions or NW winds occur about $90 \%$ of the time so that downwelling conditions prevail. Occasionally, moderate SE winds may blow for 1 to $2 \mathrm{~d}$, totalling some $10 \%$ of the winter period.

In order to evaluate the effect of the seasonal patterns of upwelling and downwelling on the biological community, we have idealised these data into simple patterns. The total percentages of strong and medium upwelling, and of downwelling, have been kept constant for summer and winter periods, but we have 
explored the ecological consequences of different water exchange rates, based on the range of turnover times of 0 to 7 times $\mathrm{d}^{-1}$ measured by Field et al. (1980b). The effect of the duration of down- and upwelling pulses has also been simulated by doubling and halving the average pulse duration while maintaining the same total proportion of each regime during summer and winter. In these simulations the biological variables were kept constant in order to judge the effect of changing hydrodynamic conditions. The biological variables (electivities and assimilation efficiencies) were set at the most reasonable estimates based on discussions with our eco-physiological colleagues in the project (Table 3).

Table 3. Electivity and assimilation efficiencies used in the simulations describing seasonal variations and pulses of downwelling and upwelling

\begin{tabular}{lcc|}
\hline & Electivity & $\begin{array}{c}\text { Assimilation } \\
\text { efficiency }\end{array}$ \\
\hline Phytoplankton & 1.00 & 0.70 \\
Kelp POM & 0.70 & 0.45 \\
Faeces & 0.70 & 0.45 \\
Bacteria & 0.80 & 0.70 \\
\hline
\end{tabular}

\section{RESULTS AND DISCUSSION}

We have used the madel as a tool to investigate the general trends in 4 situations which are described below: a closed system without imports or exports, downwelling only, upwelling only, and a combination of upwelling and downwelling in pulses based on wind measurements and the seasonal wind patterns.
The simulations were run until steady state occurred, i. e. when animal biomasses stabilised.

\section{Closed system}

The closed system simulations correspond to the budgetting model of a kelp bed described by Newell et al. (1982) and are indeed based on the same data. The simulation model has allowed us to go a stage further and ask a series of 'what if?' questions about the biological variables which are founded mainly on the work of Griffiths and King (1979a, b) and Stuart et al. (1981, 1982a, b) and Stuart (1982). Thus, we have used the model to explore the effects of large variations in food electivity and assimilation efficiencies of the filter feeders since very little is known of their energy budgets except for the mussels.

The effects of varying electivity and assimilation efficiency indices (collectively called 'feeding efficiencies' here) are shown in Fig. 2. Fig. 2a shows that a detrital food chain can maintain a large consumer biomass even if only $25 \%$ of the available kelp POM/ faeces is ingested and these assimilated with only $25 \%$ efficiency, provided that there is a supplement of some $20 \%$ of the phytoplankton/bacteria assimilated at $20 \%$ efficiency. With increasing efficiencies of feeding on phytoplankton/bacteria, the animal biomass can be maintained at the maximum for the model with even lower feeding efficiencies on kelp POM and faeces. Fig. $2 \mathrm{~b}$ shows that faeces comprise between $74 \%$ and $14 \%$ of the food of filter feeders, with the lowest values at highest feeding efficiencies, and vice versa. The isolines reveal that this relationship is not linear. If feeding efficiencies on phytoplankon/bacteria are kept constant, there is peak in the faeces
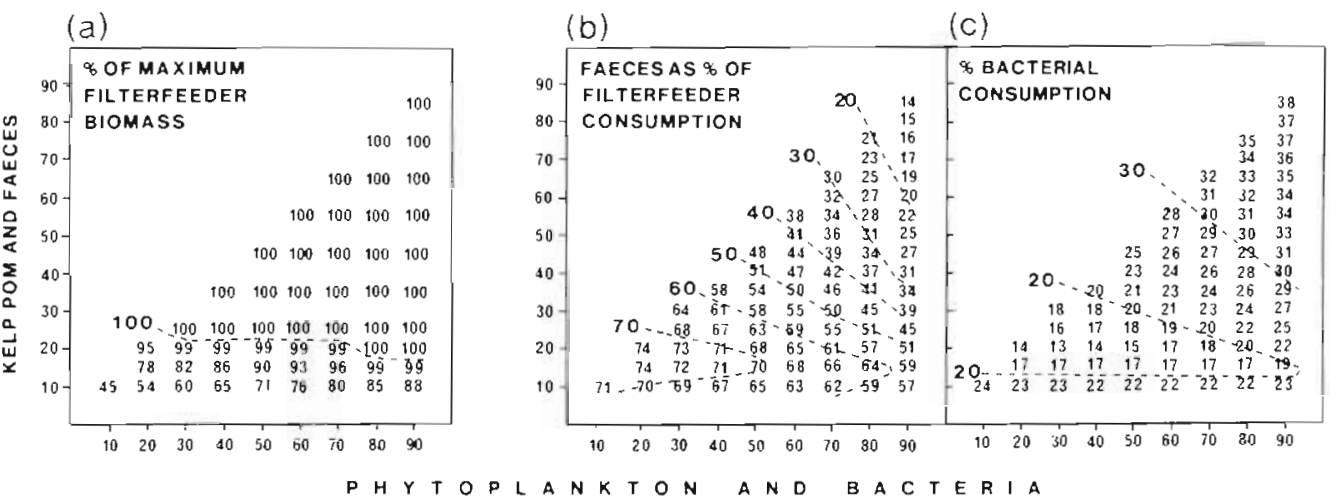

Fig. 2. Effects of varying electivity and assimilation efficiencies in a simulation model of a Benguela kelp bed. These results were obtained simulating calm conditions of high phytoplankton and low nutrient concentrations without water exchange. Electivity and assimilation efficiencies of food particles used by filter feeders are expressed as percentages of food; they were kept equal for phytoplankton and bacteria ( $\mathrm{x}$-axis) and for kelp POM and faeces (y-axis). (a) Filter feeder biomass attained at steady state with different assumptions of electivity and assimilation efficiency. (b) Proportion of faeces consumed by filter feeders under these different assumptions. (c) Proportion of POM and DOM consumed by bacteria 
content of filter feeder food. This is caused by further increases in feeding efficiencies on POM/faeces leading to decreased faecal production when no more food can be utilised, because filter feeders are controlled at their maximum biomass by predators. Fig. $2 c$ shows an inverse non-linear relationship between the proportion of DOM and POM consumed by bacteria, and feeding efficiencies of filter feeders on bacteria. This is caused by bacterial activity being related to the amount of unused food and DOM in the water column.

Under these low nutrient, closed-system conditions (what we have called downwelling conditions with zero transport') phytoplankton is present as a food supplement, and organic matter (mostly faeces) is accumulated due to the low efficiency of microbial carbon degradation. In spite of the low feeding efficiencies on faeces and kelp detritus, all the primary production can eventually be used by consumers because the same material may be consumed over and over again, until most of it is dissipated in respiration.

Downwelling is brought about by relaxation of the prevailing SE winds in summer or by onshore NW winds. Under downwelling conditions phytoplanktonrich, nutrient-poor water moves into the kelp beds (Brown, 1981; Field et al., 1981; Jarman and Carter, 1981). Accordingly we have run the model with phytoplankton being imported and bacterial conversion efficiencies set at $10 \%$ (see p. 220).

Fig. 3 shows the effect of water exchange on animal biomass during downwelling with 3 different combinations of feeding efficiencies on phytoplankton/bacteria and POM/faeces. High phytoplankton feeding efficiencies allow the maximum model biomass to be reached at slow water turnover rates, after an initial

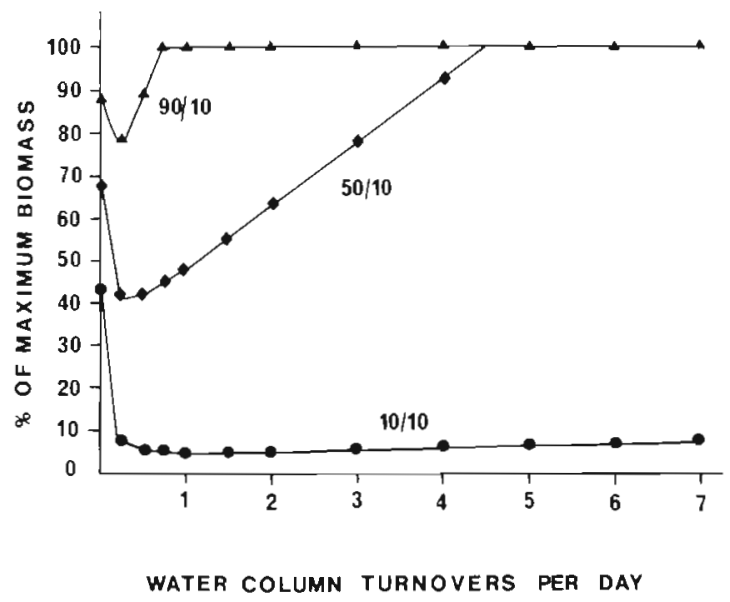

Fig. 3. Effects of water-exchange rate on filter-feeder biomass under downwelling conditions using the Benguela kelp bed simulation model. Water-exchange rate is expressed in turnovers of the water column $\mathrm{d}^{-1}$. Labels on each curve show the electivity and assimilation efficiencies used for (phytoplankton + bacteria) / (kelp POM + faeces), respectively

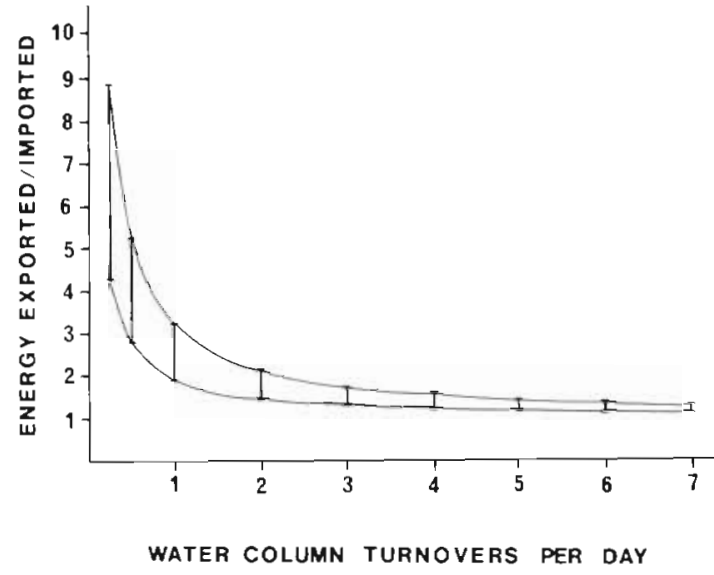

Fig. 4. Variations in the ratio between food energy exported and imported at different water-exchange rates (turnovers $\mathrm{d}^{-1}$ ), simulated with the Benguela kelp-bed model under down-welling conditions. Vertical bars: range of ratios obtained when electivity and assimilation efficiencies were changed between 10 and $90 \%$

decrease in biomass at very slow turnover rates. With $50 \%$ on phytoplankton/bacteria and low feeding efficiencies on POM/faeces, faster downwelling is required to maintain maximum biomass, and this is never attained at $10 \%$ efficiencies. Fig. 4 explains why increasing downwelling rates allow maintenance of maximal animal biomass, with $50 \%$ or higher feeding efficiencies on phytoplankton/bacteria: increasing water transport brings a greater amount of phytoplankton into and through the system from an infinitely large reservoir, but since primary production inside the system is finite and constant, it is diluted by both filter feeding and by export. Fig. 5 shows that the proportion

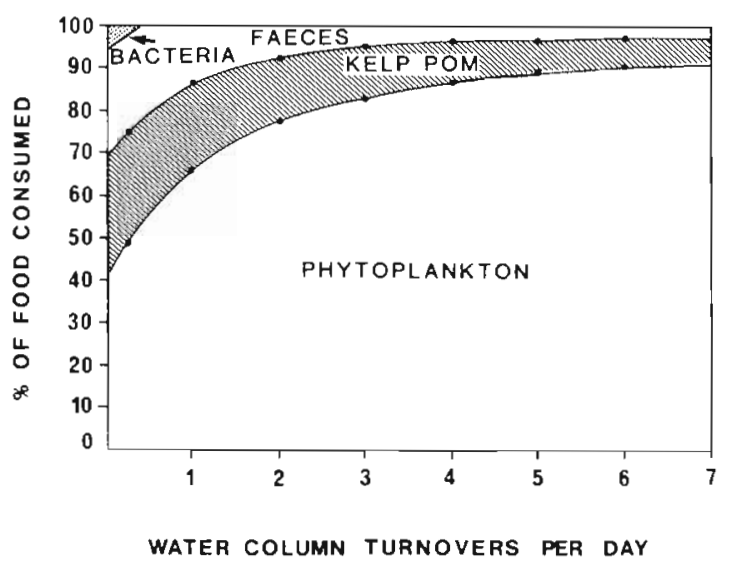

Fig. 5. Variations in composition of food consumed by filter feeders in the Benguela kelp-bed simulation model at different water-exchange rates (turnovers $\mathrm{d}^{-1}$ ) under downwelling conditions. This simulation was run under constant electivity and assimilation efficiencies set at $50 \%$, thus half of all particles can be consumed and assimilated with a $50 \%$ efficiency 
of phytoplankton in the food consumed by filter feeders increases from $40 \%$ to over $90 \%$ with increasing water exchange.

It is clear that even with very little water exchange the consumer biomass can be maintained under continuous downwelling conditions. With increasing rates of water transport the kelp detritus, faeces and bacterial components of filter-feeder diets become smaller and phytoplankton becomes more important. This is because there is a vast reservoir of phytoplankton extending to the Benguela oceanic front 10 to $90 \mathrm{~km}$ offshore (Andrews and Hutchings, 1980). In spite of the roughly equal primary production rates per unit area in kelp beds and in adjacent pelagic waters (Newell et al., 1982), the band of kelp some $500 \mathrm{~m}$ wide cannot compare quantitatively in total primary production.

\section{Continuous upwelling}

To simulate upwelling conditions, the model was set to import zero phytoplankton and to increase the bacterial carbon conversion efficiencies from $10 \%$ to $40 \%$, although both values were tried. We did this because it is well known that the southern Benguela upwelling brings clear, plankton-free water to the surface from below the euphotic zone and that phytoplankton blooms develop as the water moves offshore and is thermally stratified (Andrews and Hutchings, 1980; Brown, 1981).

The model indicates that under continuous upwelling there would be insufficient food to maintain the biomasses of consumers observed. Fig. 6 shows that even if food were selected and assimilated with $90 \%$ efficiency, only $80 \%$ of the biomass could be main-

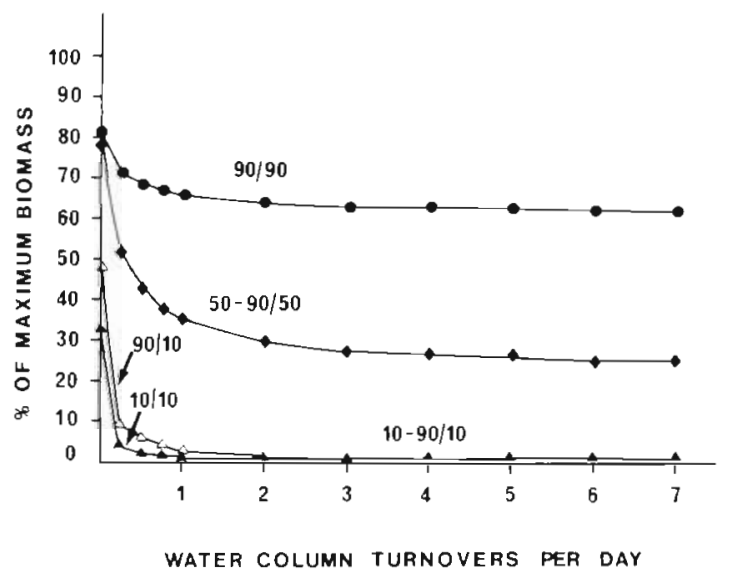

Fig. 6. Effects of water exchange (turnovers $\mathrm{d}^{-1}$ ) on filter feeder biomass under upwelling conditions using the Benguela kelp-bed simulation model. Curves are labelled to show electivity and assimilation efficiencies used for bacteria/kelp POM + faeces tained by the detritus food chain without phytoplankton. Variations in the efficiency of feeding on bacteria from 10 to $90 \%$ have less than $1 \%$ effect on consumer biomass for water exchange rates greater than $1 \mathrm{~d}^{\mathbf{1}}$. With increasing exchange rates (faster upwelling) a larger fraction of the particulate food is exported before filter feeders have the opportunity to clear it. At the same time there is a decline in the proportion of faeces and bacteria consumed (Fig. 7). If the bacterial

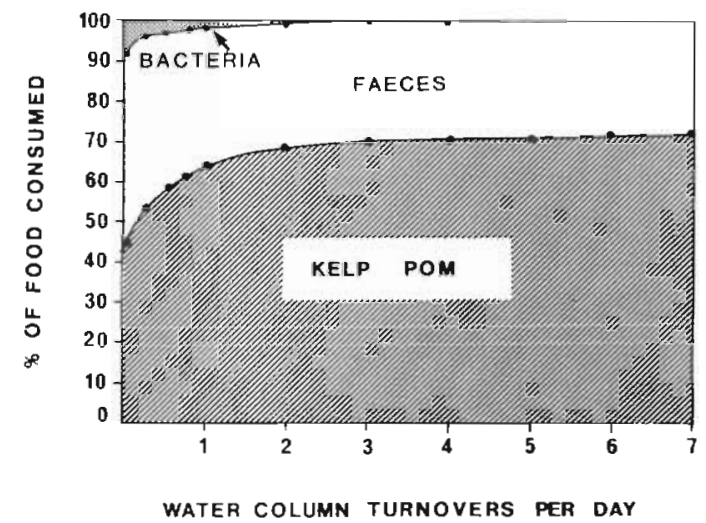

Fig. 7. Variations in composition of food consumed by filter feeders in the Benguela kelp-bed simulation model with different water-exchange rates (turnovers $\mathrm{d}^{-1}$ ) under upwelling conditions. Electivity and assimilation efficiency were kept constant at $50 \%$, thus half of the food can be consumed with an efficiency of $50 \%$

carbon conversion efficiency were $10 \%$ (as for downwelling) instead of $40 \%$, the relative importance of bacteria would decline even further. For rates faster than 2 turnovers of the water column $\mathrm{d}^{-1}$ it makes little difference how fast upwelling occurs. Even at $90 \%$ feeding efficiencies, over $30 \%$ of the POM produced is exported, whilst at lower efficiencies up to $97 \%$ is exported (Fig. 8).

It has now been documented that kelp detritus is in fact exported and can probably be detected up to $9 \mathrm{~km}$ offshore (Koop et al., 1982). It is likely that similar detritus export occurs from other nearshore upwelling communities, but we are not aware of studies elsewhere that demonstrate this.

\section{Pulsed up- and downwelling}

In reality southem Benguela kelp beds are affected by pulses of upwelling and downwelling whose frequency and duration can be estimated from an upwelling index (G. Nelson, pers, comm.). Rates of water transport have also been measured in a kelp bed (Field et al., 1981). The model was set to give the same summer and winter proportions of up- and downwell- 


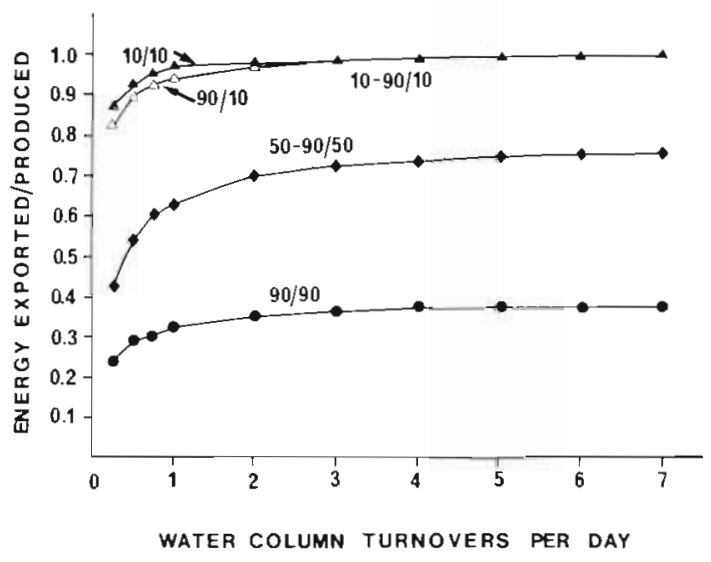

Fig. 8. Variations in ratios between energy exported and produced with different water-exchange rates (turnover $\mathrm{d}^{-1}$ ) simulated using the Benguela kelp-bed simulation model under upwelling conditions. Curve labels indicate electivity and assimilation efficiencies used for bacteria/ kelp POM + faeces

ing and the effect of varying the duration of pulses and speed of water transport was investigated. The results are not quantitative because seasonal variations in primary production due to changes in insolation and temperature have not been included. Nevertheless, the model is realistic in that higher average phytoplankton standing stocks exist in winter than in summer (Jarman and Carter, 1981).

Fig. 9 depicts the results of a simulation using the mean wind pulse lenghts and water exchange rates described on p. 221. The seasonal variations in animal

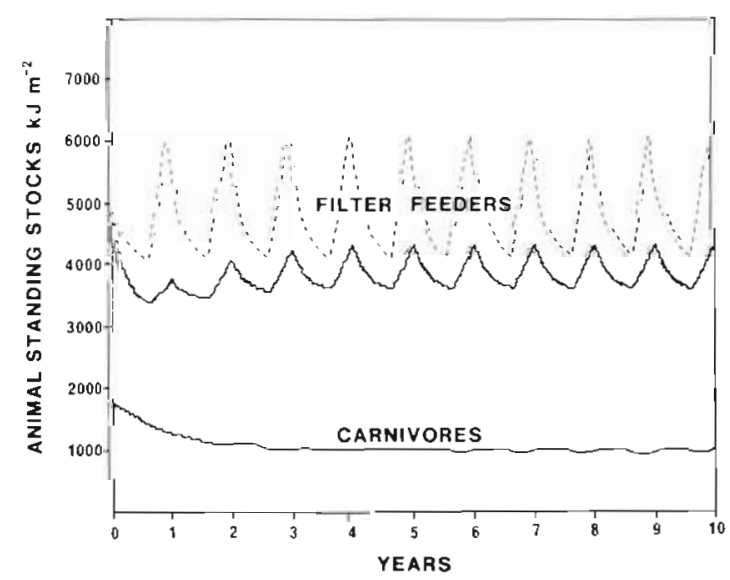

Fig. 9. Seasonal variations in filter feeder and camivore biomasses simulated using the kelp-bed model. During the 8 mo summer period a cycle of $4.2 \mathrm{~d}$ of strong upwelling followed by $2.5 \mathrm{~d}$ of moderate upwelling and $3.3 \mathrm{~d}$ of downwelling is repeated. The 4 mo winter period has cycles of $18 \mathrm{~d}$ of downwelling and $2 \mathrm{~d}$ of moderate upwelling. Broken line: variation of filter-feeder biomass under the same environmental conditions but when carnivores are excluded from the model biomasses shown are typical of all the simulations performed. Filter feeders show annual fluctuations with increasing biomass in the 4 winter months (predominantly downwelling conditions) and decreasing biomass during the summer upwelling season of $8 \mathrm{mo}$ duration. A steady state (i. e. the same minima and maxima each year), is reached after about $7 \mathrm{yr}$. The seasonal variations in carnivore biomass are much smaller, less than $1 \%$ in all cases. When carnivores are removed from the simulation, filter-feeder biomass shows large fluctuations with maxima exceeding the initial value

Table $4 \mathrm{a}$ summarizes the conditions for simulating the effect of pulse length and water exchange rate. The duration of summer (240 d) and winter (125 d) was kept constant as were the relative proportions of strong and moderate upwelling and downwelling during summer (42\%, 25\% and $33 \%$ respectively) and of moderate upwelling and downwelling during winter $(10 \%$ and $90 \%$ ). The model was also run with fast and slow rates of water exchange, giving a total of 8 combinations.

Table $4 \mathrm{~b}$ gives the results of the sensitivity analysis described above. The peaks range from 80 to $87 \%$ of the maximum biomasses when carnivores are included. In no instances do biomasses reach the initial values $\left(5,155\right.$ and $\left.1,728 \mathrm{~kJ} \mathrm{~m}^{-2}\right)$ for filter feeders and carnivores respectively, values which represent a community in steady state without food limitation. Simulations 1 to 4 , with short summer pulses, show slightly larger filter-feeder biomasses with fast exchange rates $(3,4)$ but little effect of long and short winter pulses. Simulations 5 to 8 are based on long summer pulses and both filter feeders and carnivores again show slightly higher biomasses with fast water exchange rates. Thus water exchange rate has a greater effect on the animal community than the duration of summer and winter pulses of upwelling and downwelling.

\section{CONCLUSIONS}

Fringing marine benthic plant communities like salt marshes, sea grass and kelp beds are usually characterised by high primary productivity (Teal, 1980). An obvious conclusion could be that the rich associated animal communities are supported by the plant production. However, most food-web analyses have shown that a very small fraction of the macroscopic production is consumed directly by grazers, filter feeders and deposit feeders are often dominant and the role of detritus and bacteria as major food sources have been emphasised in many recent studies, including those on the South African kelp beds as shown in the review by Newell et al. (1982).

The model presented here has deliberately been 
Table 4. (A) Conditions for the simulations testing the effect of duration of pulses of strong upwelling (S), moderate upwelling (M) and downwelling (D) and different water exchange rates. (B) Maximum and minimum biomass of filter feeders (F) and carnivores (C) at steady state with the different pulse frequencies and water-exchange levels shown in (A)

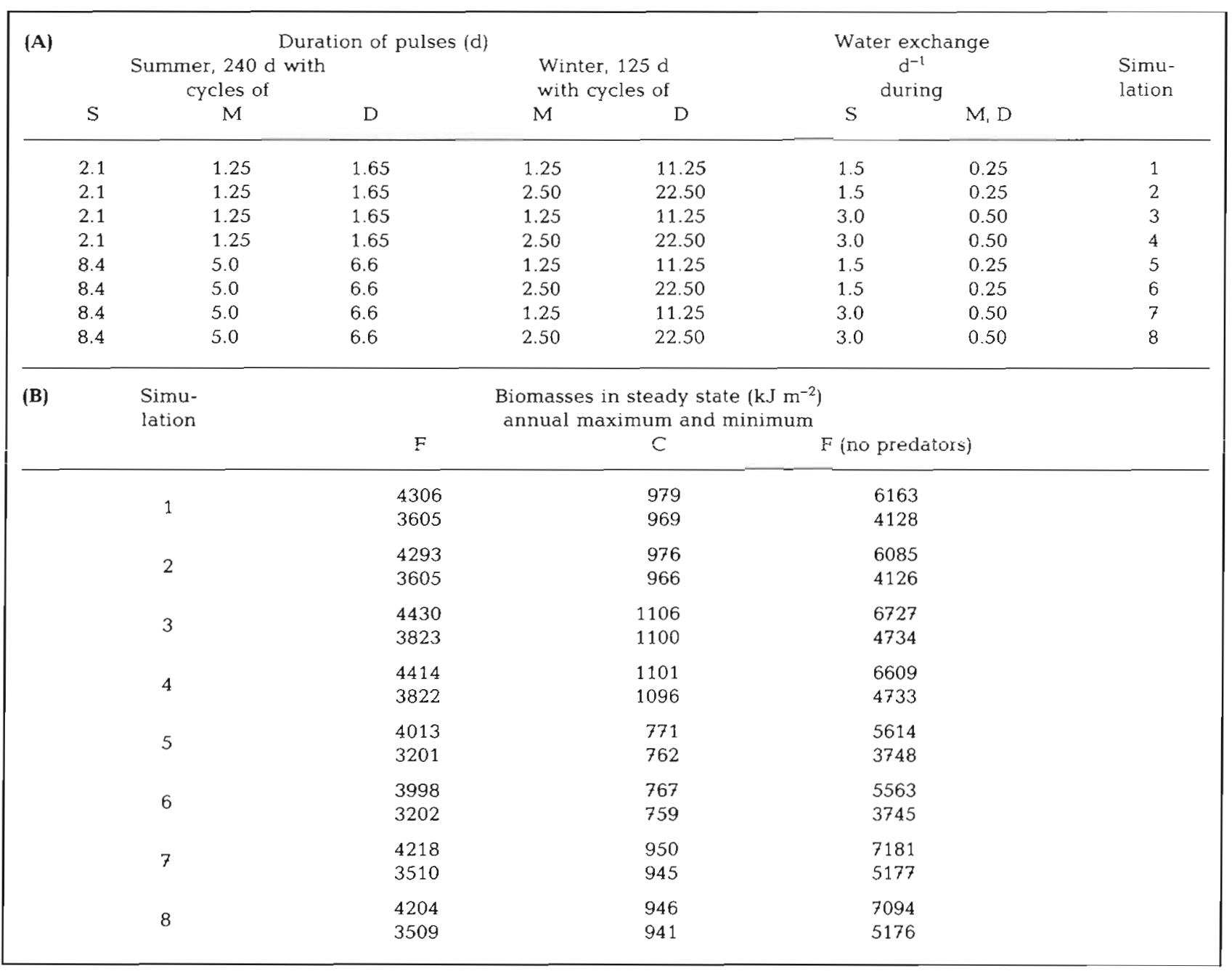

kept simple to show the effects of the very obvious advective water transport that occurs during up- and downwelling. The purpose of the modelling exercise is to understand the potential importance of the processes and structures included, not to mimic the real system in all aspects. This analysis would have been more difficult if additional features, like limiting nutrient cycles and seasonal variations of other forcing functions - such as insolation and temperature - had been included. The model has constant primary production input; filter feeders are controlled by food supply, its availability, their ability to digest it, and by predators. Feedback loops include the contribution of faeces and bacteria to the food supply and predation. Thus, although simple, the model incorporates feedback loops, imports and exports that together form a system whose dynamics are not easily understood without the use of mathematical simulations.
The simulation model of the kelp bed as a closed system showed that detrital food chains could play an important role under conditions of little water exchange, with faeces and kelp particulate matter contributing largely to the diet of filter feeders. Even at low feeding efficiencies there may be sufficient food to meet consumer requirements, since undigested food can be resuspended, colonised by microbes and filtered repeatedly. Most models of ecosystems are based on the assumption that the system is closed or that over an annual cycle, imports balance exports. This may be true for some enclosed bays, such as the kelp beds of St Margarets Bay (Nova Scotia) before destruction by sea urchins (Miller et al., 1971), and some salt marshes and estuaries (Haines, 1979; Dame and Patten, 1981). In these cases the detrital food chain with a feedback of faeces probably predominates. In more open systems with large fluxes across the boundaries, imports and 
exports may not balance and need to be taken into account.

Under continuous upwelling conditions, the model showed that consumer requirements cannot be met since kelp POM and faeces are exported. In striking contrast, under continuous downwelling conditions the system functions as a community supported to a considerable extent on imported phytoplankton. This situation is probably true for many nearshore ecosystems, such as rocky and sandy intertidal communities like the Baltic Mytilus beds (Jansson et al., 1983) and perhaps even the 'barrens' of Nova Scotia after the destruction of kelp beds, in which case sea urchins feed on phytoplankton after it has settled to the bottom as detritus (Mann, 1982).

The effect of different hydrodynamical patterns is seen most clearly in the simulation omitting carnivore control (Table $4 \mathrm{~b}$ ). Although the effects of pulse length can be seen, the effect of different rates of water exchange on biomasses is greater. Faster water movements during downwelling results in more phytoplankton being brought to the filter feeders to replace that being consumed, while during upwelling more particulate matter is exported and is not available to filter feeders.

The biomass values given as output by the model show marked seasonal fluctuations which should not be expected in nature, since the model 'biomass' is analogous to the 'scope for growth and reproduction' estimated by eco-physiologists. It does not take lipid or other energy storage or reproductive output into account. The marked effect of camivores in damping seasonal fluctuations is interesting, particularily since the main carnivore in the system is the rock lobster Jasus lalandii, which is commercially exploited. However, further inferences about rock-lobster management cannot be made from this coarse-grained model. Other models are required for that purpose, such as that of Seiderer et al. (1982), which takes the sizes of lobsters and their prey into account.

Coastal ecosystems are notoriously open, with imports and exports due to water exchange. Whilst budgetting models assuming a closed system (or balanced imports and exports) are very useful in their place, these assumptions may tend to magnify the importance of detrital food chains. The simulation model employed here has demonstrated the importance of physical advection forces, but at the same time that biological interactions - such as the feed-back loop via faeces and bacteria to POM and the control by predators - are vital to the system.

Acknowledgements. We thank our colleagues in Cape Town (South Africa), G. Nelson, R. C. Newell, V. Stuart, K. Koop, P. Brown and $R$. Carter, for valuable discussions in setting up the model. We also thank W. Wilmot, University of Stockholm
(Sweden), for help with the integration routine which was programmed in BASIC for an Apple II + computer. Our gratitude is also due to $D$. Gianakouras for preparing the figures, and to Professor P. Lasserre for facilities at the Station Biologique d'Archachon (France) where the manuscript was completed. The work was sponsored by the South African Committee for Oceanographic Research as part of the Systems Analysis Project of the Benguela Ecology Programme, by the CSIR and University of Cape Town who supported F. $\checkmark$ Wulff during his study leave at Cape Town.

\section{LITERATURE CITED}

Andrews, W. R. H., Hutchings, L. (1980). Upwelling in the southern Benguela current. Prog. Oceanogr. 9: 1-81

Barlow, R. G. (1982). Phytoplankton ecology in the southern Benguela current. III. Dynamics of a bloom. J. exp. mar. Biol. Ecol. 62

Borchers, P., Field, J. G. (1981). The effect of kelp shading on phytoplankton production. Botanica mar. 23: 89-91

Brown, P. C. (1980). Phytoplankton production studies in the coastal waters of the Cape Peninsula, South Africa. M. Sc. thesis, University Cape Town

Brown, P. C. (1981). Pelagic phytoplankton, primary production and nutrient supply in the southern Benguela region. Trans. R. Soc. S. Afr. 44: 347-355

Carter, R. (1982). Phytoplankton biomass and production in a southern Benguela kelp bed system. Mar. Ecol. Prog. Ser. 8: 9-14

Dame, R. F., Patten, B. C. (1981). Analysis of energy flows in an intertidal oyster reef. Mar. Ecol. Prog. Ser. 5: 115-124

Dieckmann, G. S. (1980). Aspects of the ecology of Laminaria pallida (Grev.) J. Ag. off the Cape Peninsula (South Africa). I. Seasonal growth. Botanica mar. 23: 579-585

Field, J. G., Jarman, N. G., Dieckmann, G. S., Griffiths, C. L., Velimirov, B., Zoutendyk, P. (1977). Sun, waves, seaweed and lobsters: the dynamics of a west coast kelp bed. S. Afr. J. Sci. 73: 7-10

Field, J. G., Jarman, N. G., Dieckmann, G. S., Griffiths, C. L., Zoutendyk, P., Velimirov, B., Bowes, A. (1980a). Variation in structure and biomass of kelp communities along the southwest Cape coast. Trans. R. Soc. S. Afr. 44: 145-203

Field, J. G., Griffiths, C. L., Linley, E. A., Carter, R. A., Zoutendyk, P. (1980b). Upwelling in a nearshore marine ecosystem and its biological implications. Estuar. coast. mar. Sci. 11: 133-150

Field, J. G., Griffiths, C. L., Velimirov, B., Zoutendyk, P., Carter, R. A. (1981). Wind-induced water movements in a Benguela kelp bed. In: Richards, F. A. (ed.) Coastal upwelling. American Geophysical Union, New York, p. $507-513$

Griffiths, C. L., King, J. A. (1979a). Some relationships between size, food availability and energy balance in the ribbed mussel Aulacomya ater. Mar. Biol. 51: 141-149

Griffiths, C. L., King, J. A. (1979b). Energy expended on growth and gonad output in the ribbed mussel Aulacomya ater. Mar. Biol. 53: 217-222

Haines, E. B. (1979). Interactions between Georgia salt marshes and coastal waters: a changing paradigm. In: Livingston, R. J. (ed.) Ecological processes in coastal and marine systems. Plenum Press, New York, p. 35-46

Jansson, B.-O., Wilmot, W., Wulff, F. V. (1983). Coupling the subsystems - the Baltic Sea as a case study. In: Fasham, M. J. (ed.) Flow of energy and materials in marine ecosystems. Plenum Press, New York 
Jarman, N. G., Carter, R. A. (1981). The primary producers of the inshore regions of the Benguela. Trans. R. Soc. S. Afr. 44: $321-326$

Koop, K., Carter, R. A., Newell, R. C. (1982). Evidence for export from kelp beds using a bioassay of substratespecific bacteria. Limnol. Oceanogr. 27: 950-954

Linley, E. A. S., Newell, R. C. (1981). Microheterotrophic communities associated with the degradation of kelp debris. In: Rheinheimer, G., Flügel, H., Lenz, J., Zeitzschel, B. (ed.) 15th European Marine Biology Symposiurn. Kieler Meeresforsch. 5: 345-355

Linley, E. A. S., Newell, R. C., Bosma, S. A. (1981). Heterotrophic utilization of mucilage released during fragmentation of kelp (Ecklonia maxima and Laminaria pallida). I. Development of microbial communities associated with the degradation of kelp mucilage. Mar. Ecol. Prog. Ser. 4: $31-41$

Lucas, M. I., Newell, R. C., Velimirov, B. (1981). Heterotrophic utilization of mucilage released during fragmentation of kelp (Ecklonia maxima and Laminaria pallida). 2. Differential utilization of dissolved organic components from kelp mucilage. Mar. Ecol. Prog. Ser. 4: 43-55

Mann, K. H. (1982). The ecoiogy of coastal waters: a systems approach. Blackwell, Oxford

Mann, K. H., Jarman, N. G., Dieckmann, G. S. (1979). Development of a method for measuring the productivity of Ecklonia maxima (Osbeck) Papenf. Trans. R. Soc S. Afr. 44: $27-42$

Miller, E. J., Mann, K. H., Scarratt, D. J. (1971). Production potential of a seaweed-lobster community in Eastern Canada. J. Fish. Res. Bd Can. 28: 1733-1738

Møhlenberg, F., Riisgård, H. U. (1978). Efficiency of particle retention in 13 species of suspension feeding bivalves. Ophelia 17: 234-246

Newell, R. C. (1983). The biological role of detritus in the marine environment. In: Fasham, M. J. (ed.) Flow of energy and materials in marine ecosystems. Plenum Press, New York

Newell, R. C., Lucas, M. I. (1981). The quantitative significance of dissolved and particulate organic matter released during fragmentation of kelp in coastal waters. Kieler Meeresforsch. 5: 356-369

Newell, R. C., Lucas, M. I., Velimirov, B., Seiderer, L. J.
(1980). Quantitative significance of dissolved organic losses following fragmentation of kelp (Ecklonia maxima and Laminaria pallida). Mar. Ecol. Prog. Ser. 2: 45-59

Newell, R. C., Lucas, M. I., Linley, E. A. S. (1981). Rate of degradation and efficiency of conversion of phytoplankton debris by marine microorganisms. Mar. Ecol. Prog. Ser. 6: 123-136

Newell, R. C., Field, J. G., Griffiths, C. L. (1982). Energy balance and significance of microorganisms in a kelp bed community. Mar. Ecol. Prog. Ser. 8: 103-113

Odum, H. T. (1972). An energy circuit language for ecological and social systems: its physical basis. In: Patten, B. C. (ed.) Systems analysis and simulations in ecology, II. Academic Press, New York, p. 139-211

Reiswig, H. M. (1974). Water transports, respiration and energetics of three tropical marine sponges. J. exp. mar. Biol. Ecol. 14: 231-249

Seiderer, L. J., Hahn, B. D., Lawrence, L. (1982) Mussels, rock lobsters and man: a mathematical model. Ecol. Modelling 17: $225-241$

Stuart, V. (1982). Absorbed ration, respiratory costs and resultant scope for growth in the mussel Aulacomya ater (Molina) fed on a diet of kelp detritus of different ages. Mar. Biol. Lett. 3: 289-306

Stuart, V., Lucas, M. I., Newell, R. C. (1981). Heterotrophic utilization of particulate matter from the kelp Laminaria pallida. Mar. Ecol. Prog. Ser. 4: 337-348

Stuart, V., Newell, R. C., Lucas, M. I. (1982a). Conversion of kelp debris and faecal material from the mussel Aulacomya ater by marine microorganisms. Mar. Ecol. Prog. Ser. 7: 47-57

Stuart, V., Field, J. G., Newell, R. C. (1982b). Evidence for the absorption of kelp detritus by the ribbed mussel, Aulacomya ater (Molina), using a new ${ }^{51} \mathrm{Cr}$-labelled microsphere technique. Mar. Ecol. Prog. Ser. 9: 263-271

Teal, J. M. (1980). Primary production of benthic and fringing plant communities, In: Mann, K. H., Barnes, R. S. (ed.) Fundamentals of aquatic ecosystems. Blackwell, Oxford, p. $67-83$

Velimirov, B., Field, J. G., Griffiths, C. L., Zoutendyk, P. (1977). The ecology of kelp bed communities in the Benguela upwelling system. Analysis of biomass and spatial distribution. Helgoländer wiss. Meeresunters. 30: 495-518 